\title{
USAHA PEMERINTAH MELINDUNGI HAK IMUNITAS ADVOKAT DALAM MELAKUKAN PEKERJAAN
}

\author{
Cinthia $^{1}$, John Calvin ${ }^{2}$, Mutiara Girindra Pratiwi ${ }^{3}$ \\ ${ }^{1}$ Jurusan Ilmu Hukum, Universitas Tarumanagara Jakarta \\ Email: Cinthiawijayaa_5@yahoo.com \\ ${ }^{2}$ Jurusan Ilmu Hukum, Universitas Tarumanagara Jakarta \\ Email: Calvin_john@live.com \\ ${ }^{3}$ Jurusan Ilmu Hukum, Universitas Tarumanagara Jakarta \\ Email: mutiaragirindrapratiwi@gmail.com
}

\begin{abstract}
Everyone involved in a case has the right of legal assistance. The Advocates' Immunity is a benchmark for an Advocate in carrying out his/her duties in accordance with the authority given by the client in a legal defense in the case handled. There are Advocates who are questioned and arrested by the Police when defending the interests of their clients. Advocate, as a honorable profession (officium nobile) and as law enforcement officers require the right of immunity to maintain independence in carrying out their duties. Article 16 of the Consitution Number 18 Year 2003 concerning Advocates states that Advocates cannot be prosecuted either in civil or criminal manner in carrying out their professional duties in good faith to defend clients in court trial, that understanding expanded by the Constitutional Court to Advocates cannot be prosecuted either in civil or criminal manner in carrying out his/her professional duties in good faith for the interest of the defense of clients inside and outside the court as long as the Advocate in carrying out his/her professional duties still adheres to the code of ethics and legislation.
\end{abstract}

Keywords: Government Efforts, Right to Immunity, Advocates

\begin{abstract}
ABSTRAK
Setiap orang yang terkena suatu perkara mempunyai hak untuk mendapatkan bantuan hukum. Hak Imunitas Advokat menjadi tolak ukur bagi seorang Advokat dalam melaksanakan tugasnya sesuai kuasa yang diberikan klien dalam pembelaan hukum dalam kasus yang ditangani. Ada Advokat yang diperiksa dan ditangkap pihak Kepolisian ketika membela kepentingan kliennya. Advokat yang berkedudukan sebagai profesi yang terhormat (officium nobile) dan sebagai aparat penegak hukum memerlukan hak imunitas untuk menjaga kemandirian dalam menjalankan profesinya. Pasal 16 Undang-Undang Nomor 18 Tahun 2003 tentang Advokat menyatakan bahwa Advokat tidak dapat dituntut baik secara perdata maupun pidana dalam menjalankan tugas profesinya dengan itikad baik untuk pembelaan klien dalam sidang Pengadilan, pengertian itu diperluas oleh Mahkamah Konstitusi menjadi Advokat tidak dapat dituntut baik secara perdata maupun pidana dalam menjalankan tugas profesinya dengan itikad baik untuk kepentingan pembelaan klien di dalam maupun di luar sidang pengadilan asalkan Advokat dalam menjalankan tugas profesinya tetap berpegangan pada kode etik dan peraturan perundang-undangan.
\end{abstract}

Kata Kunci: Usaha Pemerintah, Hak Imunitas, Advokat

\section{PENDAHULUAN}

\section{Latar belakang}

Pasal 1 Ayat (3) Undang-Undang Dasar Republik Indonesia tahun 1945 setelah di amandemen ketiga disahkan 10 Nopember 2001 menyatakan secara tegas bahwa Negara Indonesia adalah negara hukum. Prinsip dari negara hukum yaitu adanya jaminan kedudukan yang sama bagi setiap orang di hadapan hukum. Pasal 28 Huruf D Undang-Undang Dasar Republik Indonesia tahun 1945 juga menentukan bahwa setiap orang berhak atas pengakuan, jaminan, perlindungan dan kepastian hukum yang adil serta perlakuan yang sama di hadapan hukum. Disinilah tugas dan tanggung jawab dari profesi seorang advokat.

Pengertian Advokat menurut Pasal 1 Ayat (1) Undang-Undang Nomor 18 Tahun 2003 tentang Advokat adalah orang yang berprofesi memberi jasa hukum, baik di dalam maupun di luar pengadilan yang memenuhi persyaratan berdasarkan undang-undang ini. Pada ketentuan Pasal 5 ayat (1) Undang-Undang Nomor 18 Tahun 2003 tentang Advokat menyebutkan "Advokat berstatus sebagai penegak hukum, bebas dan mandiri yang dijamin oleh hukum dan peraturan 
Perundang-undangan", maka kedudukan Advokat adalah setara atau sederajat dengan aparat penegak hukum lainnya (Polisi, Jaksa, Hakim). Realita praktik penegakan hukum oleh advokat di Indonesia meskipun sama-sama sebagai penegak hukum, peran dan fungsi para penegak hukum ini berbeda satu sama lain. Kemandirian dan kebebasan yang dimilik seorang yang berprofesi sebagai Advokat harus diikuti oleh adanya tanggung jawab dari masing-masing Advokat dan organisasi profesi yang menaunginya. Sebagaimana yang telah diatur oleh Undang-Undang Nomor 18 Tahun 2003 tentang Advokat, bahwa Organisasi Advokat wajib menyusun kode etik advokat untuk menjaga martabat dan kehormatan profesi advokat sebagai profesi yang mulia dan terhormat.

Pada dasarnya tugas pokok dari seorang penasihat hukum atau yang biasa kita sebut dengan pengacara (advokat) merupakan jabatan yang mulia. Dikatakan mulia karena tujuan dari profesi advokat ini adalah untuk membantu klien atau pemberi kuasa yang mempercayainya untuk mempertahankan dan memperjuangkan hak-haknya di forum yang telah ditentukan. Seorang Advokat harus memegang teguh prinsip equality before the law dan azas "praduga tidak bersalah" (presumption of innocence), agar di dalam pembelaan dan tugasnya sehari-hari ia berani menjalankan profesi dan fungsinya dengan efektif. Terlebih lagi kalua ia dilengkapi pengetahuan hukum yang memadai, maka tidak ada alasan kenapa ia harus takut menghadapi perkara-perkara apapun juga dan betapapun beratnya perkara tersebut (Winarta Frans Hendra, 1995).

Khusus advokat, menjadi sangat penting posisinya mengingat peranannya bilamana anggota masyarakat berhadapan dengan pengadilan. Tidak berlebihan bila dikatakan, bahwa advokat adalah institusi yang paling dekat dengan rakyat dibandingkan dengan Lembaga lainnya yang terkait dengan peradilan tadi. Oleh karena itu, dapat dikatakan bahwa adanya profesi advokat yang bebas pun merupakan syarat mutlak bagi terwujudnya peradilan yang bebas dan mandiri, sebagaimana dikehendaki oleh berbagai ketentuan tadi. Tanpa ada hal tersebut, mustahil dapat tercapai cita-cita peradilan yang bebas dan mandiri (Winarta Frans Hendra, 1995).

Advokat juga memiliki hak imunitas yang melekat dalam dirinya. Hak imunitas pada profesi advokat sebenarnya bukan hal yang baru, namun yang menjadi menarik adalah mengenai perkembangan hak imunitas tersebut dalam perkembangan saat ini. Pada awalnya hak imunitas advokat mengacu pada Pasal 16 Undang-Undang Nomor 18 Tahun 2003 tentang Advokat bahwa advokat tidak dapat dituntut baik secara perdata maupun pidana dalam menjalankan tugas profesinya dengan itikad baik untuk pembelaan klien dalam sidang pengadilan. Putusan Mahkamah Konstitusi Nomor 26/PUU-XI/2013 memberikan perluasan ruang lingkup imunitas advokat sehingga menjadi advokat tidak dapat dituntut baik secara perdata maupun pidana dalam menjalankan tugas profesinya dengan itikad baik untuk pembelaan klien baik di dalam sidang pengadilan maupun di luar sidang pengadilan. Artinya, sejak Putusan Mahkamah Konstitusi Nomor 26/PUU-XI/2013 advokat memiliki imunitas baik di dalam maupun di luar pengadilan (Elba Damhuri, 2018). Penjelasan Pasal 16 Undang-Undang Advokat menegaskan bahwa dalam menjalankan tugas profesi demi tegaknya keadilan berdasarkan hukum untuk membela kepentingan klien. Imunitas bukan hak yang dimiliki oleh Advokat sebagai seseorang yang memiliki profesi dalam menegakkan hukum. Namun, hak itu adalah imunitas. Hak imunitas diberikan guna mendukung optimalnya peran dan tugas Advokat dalam rangka penegakan hukum.

Namun pada kenyataan di masyarakat, masih banyak Advokat yang dituntut atas perbuatannya yang bertujuan untuk membela kliennya. Kasus baru-baru ini mengenai Advokat yang dituntut atas perbuatannya yang bertujuan untuk membela kliennya adalah Mantan Advokat Setya Novanto yaitu Fredrich Yunadi yang hanya menjalankan profesinya untuk kepentingan membela kliennya 
dalam persidangan atas kasus korupsi proyek Kartu Tanda Penduduk Elektronik (E-KTP). Oleh sebab itu, maka penulis tertarik untuk menulis mengenai hak imunitas dalam profesi advokat

\section{Rumusan masalah}

Faktor-faktor apakah yang menjadi kendala pelaksanaan hak imunitas Advokat?

\section{HASIL DAN PEMBAHASAN \\ Teori asas legalitas}

Asas yang esensinya terdapat dalam ungkapan nullum delictum, nulla poena sine praevia lege poenali yang dikemukakan oleh von Feurbach. Ungkapan itu mengandung pengertian bahwa "tidak ada suatu perbuatan yang dapat dipidana kecuali atas perundang-undangan pidana yang sudah ada sebelum perbuatan itu dilakukan". Perundangundangan atau Hukum yang diartikan sebagai aturan yaitu perangkat hukum suatu negara yang mampu menjamin hak dan kewajiban setiap warga Negara (KBBI). Asas legalitas adalah asas yang paling penting dalam hukum pidana, khususnya asas pokok dalam penetapan kriminalisasi.

Menurut J.E. Sahetapy asas legalitas mengandung tujuh makna, yaitu (Sahetapy, 1996):

a. Tidak dapat dipidana kecuali berdasarkan ketentuan pidana menurut undang-undang;

b. Tidak ada penerapan Undang-Undang pidana berdasarkan analogi;

c. Tidak dapat dipidana hanya berdasarkan kebiasaan;

d. Tidak boleh ada perumusan delik yang kurang jelas (syarat lex certa);

e. Tidak ada kekuatan surut dari ketentuan pidana;

f. Tidak ada pidana lain kecuali yang ditentukan UndangUndang; dan

g. Penuntutan pidana hanya menurut cara yang ditentukan Undang-Undang;

\section{Advokat sebagai profesi terhormat}

Salah satu komitmen dan agenda reformasi yang dicanangkan pada tahun 1998 adalah mewujudkan sebuah pemerintahan yang bersih (clean government) yang bebas dari korupsi, kolusi, dan nepotisme (KKN) (Mukthie Fadjar, 2009). Salah satu bentuk komitmen dalam melaksanakan agenda reformasi tersebut adalah melakukan perbaikan dan pembenahan dalam bidang hukum utamanya terfokus pada masalah penegakan hukum, tetapi setelah 17 (tujuh belas tahun) reformasi bergulir hingga kini masalah penegakan hukum belum juga menampakkan hasil yang signifikan sesuai tujuannya yaitu memberikan perlindungan dan rasa keadilan bagi warga masyarakat sehingga dapat menciptakan masyarakat yang sejahtera, adil dan makmur sebagaimana yang dicitacitakan dalam Proklamasi. Reformasi dalam bidang hukum selain dengan melakukan perubahan dan pembaharuan total terhadap seluruh bagian sistem hukum (legal system) juga penegakan hukum (law enforcement), sehingga harus pula menyentuh pada upaya perbaikan dan pembenahan terhadap lembaga dan aparat penegak hukum baik hakim, jaksa, polisi dan termasuk advokat (lawyer). Sebagai konsekuensi reformasi tersebut pada periode tahun 1999 sampai dengan tahun 2015 telah dilakukan beberapa kali perubahan terhadap Konstitusi Negara Republik Indonesia, yaitu Undang-undang Dasar Tahun 1945 (selanjutnya disebut UUD 1945). Beberapa perubahan terhadap UUD 1945 tersebut membawa implikasi perubahan besar dalam sistem ketatanegaraan Indonesia, baik dalam pelembagaan kekuasaan legislatif, eksekutif, maupun yudikatif (kekuasaan kehakiman). Akibat dari perubahan pengaturan kekuasaan kehakiman dalam UUD 1945, telah dikeluarkan beberapa undang-undang yang terkait dengan kekuasaan kehakiman khususnya Undang-undang Nomor 18 Tahun 2003 tentang Advokat. Setelah dilakukan amandemen atau perubahan Undang-undang Dasar 1945 (saat ini dikenal sebagai Undang-undang Dasar Negara Republik Indonesia Tahun 1945 yang selanjutnya disebut UUD NRI 1945) pengaturan kekuasaan kehakiman lebih lengkap, meliputi adanya penegasan bahwa badan-badan lain yang fungsinya berkaitan dengan kekuasaan kehakiman akan diatur dalam Undang-Undang 
(termasuk pengaturan tentang advokat), sebagaimana dalam Pasal 24 UUD NRI 1945 menyatakan sebagai berikut:

a. Kekuasaan kehakiman merupakan kekuasaan yang merdeka untuk menyelenggarakan peradilan guna menegakkan hukum dan keadilan;

b. Kekuasaan kehakiman dilakukan oleh sebuah Mahkamah Agung dan badan peradilan yang berada di bawahnya dalam lingkungan peradilan umum, lingkungan peradilan agama, lingkungan peradilan militer, lingkungan peradilan tata usaha negara, dan oleh sebuah Mahkamah Konstitusi;

c. Badan-badan lain yang fungsinya berkaitan dengan kekuasaan kehakiman diatur dalam Undang-Undang.

Kekuasaan kehakiman berfungsi sebagai lembaga pengontrol terhadap pelaksanaan hukum dalam negara hukum. Sedemikian pentingnya lembaga kontrol terhadap berlakunya hukum ini sehingga mutlak diperlukan suatu lembaga kekuasaan kehakiman yang tidak hanya sekedar ada, memiliki fasilitas yang diperlukan, mampu menyelesaikan perkara yang muncul, namun lebih dari itu juga harus bersyaratkan sebuah predikat yang bersih dan berwibawa dalam rangka untuk mewujudkan penegakan hukum dan keadilan (Wisnobroto, 1997). Badan-badan lain yang fungsinya berkaitan dengan kekuasaan kehakiman yang merdeka, salah satunya, adalah organisasi profesi advokat Advokat sering dipertukarkan dengan Lawyer yang menurut Black Law Dictionary diartikan sebagai "A person learned in law; as an attorney, counsel, or solicitor; a person licensed to practice law. "Any person who persecutes or depends causes in courts of record or other judicial tribunals of the United State; or of any of the states, or while business it is to give legal advice or assistance in relation to any cause or matter whatever" (Black, 1991). Pada Konsideran UndangUndang Nomor 18 Tahun 2003 tentang Advokat Huruf B dinyatakan bahwa profesi Advokat adalah profesi terhormat (officium nobile) yang dalam menjalankan profesinya berada di bawah perlindungan hukum, undang-undang dan kode etik, memiliki kebebasan yang didasarkan kepada kehormatan dan kepribadian Advokat yang berpegang teguh kepada kemandirian, kejujuran, kerahasiaan dan keterbukaan.

Ada dua fungsi advokat dalam terciptanya keadilan yang perlu mendapat perhatian, yaitu pertama, mewakili klien untuk menegakkan keadilan, dan peran advokat penting bagi klien yang diwakilinya, kedua, membantu klien, seseorang advokat mempertahankan legitimasi sistem peradilan dan fungsi advokat (Daryl Koehn, 2000). Selain kedua fungsi advokat tersebut yang tidak kalah pentingnya yaitu bagaimana advokat dapat memberikan pencerahan di bidang hukum dengan cara memberikan penyuluhan hukum, sosialisasi berbagai peraturan perundang- undangan, konsultasi hukum kepada masyarakat baik melalui media cetak, elektronik maupun secara langsung (Solehoddin, 2009). Fungsi advokat untuk membela kliennya adalah menegakkan "asas praduga tak bersalah (Presumption of Innocence)" (Edi Krisharyanto, 2007). Hal tersebut sesuai dengan ketentuan yang diatur dalam International Covenant on Civil and Political Rights atau Konvensi Internasional tentang Hak-hak Sipil dan Politik pada Pasal 14 Ayat (2) dan Ayat (3), terjemahannya kurang lebih sebagai berikut:

2) Siapapun yang dituntut melakukan tindak kejahatan berhak untuk dianggap tidak bersalah sampai terbukti bersalah menurut hukum;

3) Ketika menentukan tuduhan tindak kejahatan apapun terhadap seseorang, dia berhak untuk mendapatkan jaminan minimal dalam pemenuhan keadilan sebagai berikut:

a) Segera diberitahu dan dalam bahasa yang dia pahami mengenai hakekat dan penyebab tuduhan yang diarahkan kepadanya;

b) Memiliki waktu dan fasilitas yang cukup untuk mempersiapkan pembelaannya dan berkomunikasi dengan pengacara pilihannya; 
c) Diupayakan tidak ada penundaan yang tak semestinya;

d) Diupayakan kehadirannya dan mempertahankan dirinya sendiri atau melalui bantuan hukum pilihannya sendiri, diberitahu apa tuduhan yang telah ditetapkan kepadanya, atau apapun yang memang diperlukan demi keadilan dan tanpa harus membayar jika dia tidak mempunyai uang untuk membayarnya;

e) Menyelidiki, atau memiliki penyelidikan atas saksi demi kepentingannya di bawah kondisi yang sama sebagaimana saksi demi kepentingan dirinya;

f) Mendapatkan bantuan bebas penerjemah lisan jika dia tidak bisa memahami atau menuturkan bahasa yang digunakan di pengadilan;

g) Tidak dipaksa memberikan kesaksian terhadap dirinya atau mengaku bersalah.

\section{Batasan hak imunitas advokat}

Ada beberapa alasan mengapa seorang Advokat dalam menjalankan profesinya dituntut oleh klien atau orang lain, padahal dalam Undang-Undang Nomor 18 Tahun 2003 tentang Advokat jelas mengatur tentang perlindungan hukum terhadap Advokat dalam menjalankan profesinya.

Jika advokat dalam menjalankan profesinya terjerat masalah hukum maka aparat penegak hukum (Polisi, Jaksa, KPK) tidak serta merta memanggil advokat yang bersangkut untuk dimintai keterangan, apalagi diperlakukan tidak wajar. Aparat penegak hukum harus memanggil advokat yang bersangkutan melalu organisasi advokat, kemudian organisasi advokatlah yang mempunya kewenangan untuk memanggil advokat yang bersangkutan guna dimintai keterangan dan penjelasan terkait dengan pemanggilan tersebut. Kemudian organisasi advokat merekomendasikan advokat yang bersangkutan untuk mendatangi pemanggilan dan menghadapi permasalahan yang menimpa advoka tersebut sekaligus memberikan pembelaan dan perlindungan profesi terhadap advokat yang bersangkuatan.

Adnan Buyung Nasution dalam Frans Hendra Winata, mengungkapkan bahwa profesi advokat adalah free profesional; kebebasan profesi tidak sekedar demi profesi advokat itu sendiri, melainkan juga guna mewujudkan kepentingan yang lebih luas yaitu terciptanya lembaga peradilan yang bebas; independent judiciary yang merupakan prasyarat dalam menegakkan rule of law dan melaksanakan nilai-nilai demokrasi (Frans Hendra Winata, 1995).

Selain free profesional, profesi advokat adalah merupakan profesi privat yang menjalankan fungs publik, oleh karenanya advokat dalam menjalankan profesinya sebagai penegak hukum seharusnya diberikan hak imunitas secara utuh. Senada dengan hal tersebut di atas, dalam Putusan Mahkamah Konstitusi (selanjutnya disebut MK) Perkara No. 014/PUU-IV/2006, secara tegas dinyatakan bahwa Perhimpunan Advokat Indonesia (PERADI) sebagai satu-satunya wadah profesi Advokat pada dasarnya adalah organ negara dalam arti luas yang bersifat mandiri (independen state organ) yang juga melaksanakan fungsi negara (Vide Putusan Mahkamah Nomor 066/PUU-II/2004).

Fungsi negara yang dimaksud oleh Mahkamah Konstitusi, dengan merujuk pada putusan atas perkara Nomor 006/PUU-II/2004 adalah kewajiban para advokat pada umumnya untuk memberikan akses pada keadilan bagi semua orang. Organ adalah bentuk atau wadahnya, sedangkan fungsi adalah isinya; organ adalah status bentuknya (Inggris: form, Jerman: vorm), Sedangkan Fungsi adalah gerakan wadah itu sesuai dengan pembentukannya. Dala naskah UUD 1945, organ-organ yang dimaksud, ada yang disebut secara eksplisit namanya, dan ada pula yang disebutkan eksplisit hanya fungsinya. Ada pula lembaga atau organ yang disebutkan bahwa baik namanya maupun fungsi atau kewenangannya diatur dengan peraturan yang lebih rendah (Asshiddiqie, 2005). Organisasi advokat pada dasarnya adalah organ negara yang bersifat mandiri 
yang juga melaksanakan fungsi negara, sudah seharusnya dalam menjalankan fungsi dan tugasnya, advokat diberikan kewenangan sama halnya seperti Polisi, Jaksa dan Hakim sehingga ada perimbangan di dalam menjalankan profesinya sebagai aparat penegak hukum guna menegakan keadilan dan kepastian hukum. Secara teori, kemandirian penegakan hukum di antara penegak hukum, yang paling mandiri (independency) adalah kekuasaan kehakiman (yudiciary power) dan Advokat (lawyer). Perbedaannya bahwa advokat bebas memasuki setiap tahapan dan jenis-jenis perkara: pidana, perdata, hukum administrasi pemerintahan, hukum tata negara, hukum konstitusi, litigasi maupun non-litigasi dalam kasus-kasus keperdataan. Sedangkan kekuasaan kehakiman terbatas independensinya, namun sangat menentukan warna hukum di tengah-tengah masyarakat yaitu kaitannya mengadili dan memeriksa satu perkara yang dimintakan untuk diperiksa dan diputus oleh para pihak yang bersengketa.

Hak imunitas sangat penting bagi advokat dalam menjalankan fungsi dan tugasnya sebagai aparat penegak hukum demi terciptanya keadilan, kepastian dan kemanfaatan. Pasal 16 Nomor 18 Tahun 2003 tentang Advokat mengatur tentang hak imunitas advokat dalam menjalankan profesinya sebagai aparat penegak hukum. Secara lengkap pasal 16 Nomor 18 Tahun 2003 tentang Advokat berbunyi: "Advokat tidak dapat dituntut baik secara perdata maupun pidana dalam menjalankan tugas profesinya dengan itikad baik untuk pembelaan klien dalam sidang Pengadilan". Penjelasan Pasal 16 menyatakan, yang dimaksud dengan "itikad baik" adalah menjalankan tugas profesi demi tegaknya keadilan berdasarkan hukum untuk membela kepentingan kliennya. Yang dimaksud dengan "sidang pengadilan" adalah sidang pengadilan dalam setiap tingkat pengadilan di semua lingkungan peradilan". Jadi, terdapat batasan hak imunitas seorang advokat saat menerima kuasa dari seorang klien. Batasan tersebut adalah bahwa seorang advokat dilindungi saat ia menjalani tugasnya adalah "iktikad baik" dan "dalam sidang pengadilan".

Batasan dalam sidang pengadilan adalah setiap tindakan yang diperlukan saat melakukan proses persidangan itu sendiri, baik di pengadilan tingkat pertama hingga peninjauan kembali. Tindakan tersebut meliputi pula pendapat-pendapat ataupun pernyataan-pernyataan yang dikeluarkan advokat selama persidangan, baik kepada klien maupun kepada lawannya, adovakat tidak dapat digugat atau dituntut terkait dengan pernyataan-pernyataannya tersebut.

Pasal 16 Undang-Undang Nomor 18 Tahun 2003 menyebutkan Advokat tidak dapat dituntut baik secara perdata maupun pidana dalam menjalankan tugas profesinya dengan iktikad baik untuk kepentingan pembelaan Klien dalam sidang pengadilan. Akan tetapi hak imunitas yang diberikan oleh Undang undang Nomor 18 Tahun 2003 tidak berjalan sebagaimana mestinya, tidak sedikit Advokat dalam menjalankan profesinya terjerat masalah hukum dan akhirnya menjadi Tersangka. Kasus baru-baru ini mengenai Advokat yang dituntut atas perbuatannya yang bertujuan untuk membela kliennya adalah Mantan Advokat Setya Novanto yaitu Fredrich Yunadi yang hanya menjalankan profesinya untuk kepentingan membela klien dalam persidangan atas kasus korupsi proyek Kartu Tanda Penduduk Elektronik (E-KTP).

Perlu adanya pembatasan pemaknaan terhadap bunyi pasal tersebut khususnya frase ".....dalam menjalankan tugas profesinya dengan itikad baik untuk kepentingan pembelaan klien dalam sidang pengadilan". Artinya bahwa advokat dalam menjalankan profesinya harus benar-benar berdasarkan hukum dan kode etik advokat (canons of ethics).

Profesi hukum menuntut persyaratan dan standarisasi yang tinggi terhadap seorang advokat dalam menjalankan profesinya karena profesi advokat bersinggungan dengan penerapan hukum dan nilai etika. Advokat dalam menjalankan profesinya tidak diperbolehkan melakukan hal-hal yang justru 
melanggar hukum dan kode etik dengan berlindung di balik hak imunitas. Namun dalam perkembangannya, Mahkamah Konstitusi mengabulkan permohonan perkara Nomor 26/PUUXI/2013 tentang pengujian Pasal 16 Nomor 18 Tahun 2003 tentang Advokat. Dalam pertimbangannya, Mahkamah Konstitusi menyatakan berdasarkan Pasal 1 angka 1 UndangUndang Nomor 18 Tahun 2003 tentang Advokat ditentukan bahwa advokat adalah orang yang berprofesi memberi jasa hukum, baik di dalam maupun di luar pengadilan yang memenuhi persyaratan berdasarkan ketentuan Undang-undang ini. Jadi menurut Mahkamah Konstitusi, peran advokat berupa pemberian konsultasi hukum, bantuan hukum, menjalankan kuasa, mewakili, mendampingi, membela, dan melakukan tindakan hukum lain untuk kepentingan hukum klien dapat dilakukan baik di dalam maupun di luar pengadilan. Peran advokat di luar pengadilan tersebut telah memberikan sumbangan berarti bagi pemberdayaan masyarakat serta pembaruan hukum nasional termasuk juga dalam penyelesaian sengketa di luar pengadilan. Oleh karena itu, tujuan Undang-Undang Nomor 18 Tahun 2003 tentang Advokat di samping melindungi advokat sebagai organisasi profesi, yang paling utama adalah melindungi masyarakat dari jasa advokat yang tidak memenuhi syarat-syarat yang sah atau dari kemungkinan penyalahgunaan jasa profesi advokat. Pasal 15 Undang-Undang Nomor 18 Tahun 2003 tentang Advokat bahwa advokat dalam menjalankan tugas profesinya untuk membela klien tetap berpegangan pada kode etik dan peraturan perundang-undangan. Kode etik membebankan kewajiban pada setiap advokat dalam melakukan tugasnya untuk tidak bertujuan memperoleh imbalan materi semata, tetapi lebih mengutamakan tegaknya hukum, kebenaran, dan keadilan. Dengan demikian, hak imunitas advokat bukan hanya diberikan dalam sidang pengadilan, tapi berlaku juga di luar persidangan dengan catatan bahwa di luar persidangan tersebut merupakan bagian yang tidak terpisahkan dari proses peradilan.

Jadi Hak Imunitas tidak boleh ditafsirkan secara sempit dan juga tidak boleh melampaui batas, khususnya apabila telah terjadi pelanggaran norma hukum pidana misalnya melakukan praktik penyuapan saat menjalan tugas profesinya, maka Advokat tentu tidak bisa menggunakan dalil imunitas sebagai dasar pembenaran tindakannya tersebut.

Advokat merupakan bagian dari penegak hukum yang sejajar dengan instansi penegak hukum lainnya. Pada Undang-Undang Nomor 18 Tahun 2003 tentang Advokat ditegaskan bahwa seorang Advokat berstatus sebagai penegak hukum, bebas dan mandiri yang dijamin oleh hukum dan peraturan perundang-undangan. Kewenangan Advokat sebagai Penegak Hukum ialah guna memberikan bantuan hukum kepada kliennya yang bersangkutan dengan masalah hukum yang dihadapi dan lembaga penegak hukum di luar pemerintahan. Peranan seorang advokat dalam rangka menuju sistem peradilan pidana terpadu sangat diperlukan hingga tercapai perlindungan terhadap hak-hak asasi manusia dan juga memberikan bantuan hukum kepada klien yang bersangkutan dengan masalah hukum yang dihadapi serta sebagai lembaga penegak hukum di luar pemerintahan. Dengan adanya asas legalitas maka seroang pengacara harus memiliki aturan yang wajib ditaati. Aturan itu Undang-Undang Nomor 18 Tahun 2003 tentang Advokat yang bertujuan untuk melindungi seorang Advokat. Pada dasarnya Advokat memiliki Hak Imunitas sesuai UndangUndang Nomor 18 Tahun 2003 tentang Advokat Pasal 14 sampai dengan Pasal 16, Advokat tidak dapat dituntut baik secara perdata ataupun pidana dalam menjalakan tugas profesinya dengan itikad baik untuk pembelaan klien di dalam maupun di luar pengadilan. Secara garis besar, advokat yang tidak memiliki itikad baik dalam menjalakan tugas profesinya adalah advokat yang bisa terseret ke pengadilan, atau dengan kata lain kehilangan hak imunitas itu sendiri. Melihat dari perundang-undangan ataupun aturan yang ada sekarang, tidak menjamin hak imunitas advokat di masa mendatang. Hal ini dikarenakan penjelasan undang-undang yang ada masih sangat multitafsir 


\section{Simpulan dan Saran \\ Simpulan}

Profesi advokat adalah free professional; kebebasan profesi tidak sekedar demi profesi advokat itu sendiri, melainkan juga guna mewujudkan kepentingan yang lebih luas yaitu terciptanya lembaga peradilan yang bebas; independentt judiciary yang merupakan prasyarat dalam menegakkan rule of law dan melaksanakan nilai-nilai demokrasi. Selain free professional, profesi advokat merupakan profesi privat yang menjalankan fungsi publik. Oleh sebab itu, advokat dalam menjalankan profesinya sebagai penegak hukum seharusnya diberikan hak imunitas secara utuh.

Hak imunitas sangat penting bagi advokat dalam menjalankan fungsi dan tugasnya sebagai aparat penegak hukum demi terciptanya keadilan, kepastian dan kemanfaatan. Dalam Pasal 16 UndangUndang Nomor 18 Tahun 2018 tentang Advokat berbunyi: "Advokat tidak dapat dituntut baik secara perdata maupun pidana dalam menjalankan tugas profesinya dengan itikad baik untuk pembelaan klien dalam sidang Pengadilan”. Berdasarkan penjelasan di Pasal 16, yang dimaksud dengan "itikad baik" adalah menjalankan tugas profesi demi tegaknya keadilan berdasarkan hukum untuk membela kepentingan kliennya. Perlu adanya suatu pembatasan dalam memaksai bunyi dari Pasal 16 tersebut. Artinya, bahwa advokat dalam menjalankan profesinya harus benarbenar berdasarkan hukum dan kode etik advokat.

Menurut Mahkamah Konstitusi, peran advokat berupa pemberian konsultasi hukum, bantuan hukum, menjalankan kuasa, mewakili, mendampingi, membela dan melakukan tindakan hukum lain untuk kepentingan hukum klien dapat dilakukan baik di dalam maupun di luar pengadilan. Dengan demikian, hak imunitas advokat bukan hanya diberikan dalam sidang pengadilan, tapi berlaku juga di luar persidangan dengan catatan bahwa di luar persidangan tersebut merupakan bagian yang tidak terpisahkan dari proses peradilan.

Jadi hak imunitas tidak boleh ditafsirkan secara sempit dan juga tidak boleh melampaui batas. Khususnya bila terjadi pelanggaran norma hukum pidana seperti melakukan praktik penyuapan saat menjalankan tugas profesinya, maka Advokat tentu tidak dapat menggunakan dalil imunitas sebagai dasar pembenaran atas tindakannya tersebut. Secara garis besar, advokat yang tidak memiliki itikad baik dalam menjalankan tugas profesinya adalah advokat yang bisa terseret ke pengadilan, atau dengan kata lain kehilangan hak imunitas itu sendiri. Bila dilihat dari perundangundangan ataupun aturan yang berlaku saat ini, tidak menjamin hak imunitas di masa yang akan datang. Hal ini dikarenakan penjelasan undang-undang yang masih sangat multi-tafsir.

\section{Saran}

Berdasarkan simpulan tersebut di atas maka dapat diberikan saran sebagai berikut:

a. Penilaian negatif masyarakat terhadap Advokat tidak terlepas dari sepak terjang dari Advokat sendiri karena dalam menjalankan tugas dan fungsinya sebagai aparat penegak hukum tidak sesuai dengan harapan, dan sangat disayangkan sebagian kecil Advokat menjadi bagian dari mafia peradilan. Oleh karena itu, diperlukan Advokat yang berintelektual, profesional, dan berintegritas guna menjaga marwah profesi Advokat sebagai profesi yang terhormat (Officium Nobile) dalam menegakkan hukum.

b. Dalam Undang-Undang Nomor 18 Tahun 2003 tentang Advokat mengenai Hak Imunitas yang dimiliki Advokat harus dijelaskan lebih mendetail agar tidak terjadi multi-tafsir. 


\section{Ucapan Terima Kasih (Acknowledgement)}

Penulis berterima kasih kepada partisipan yang terlibat dalam penelitian ini. Penulis juga mengucapkan terima kasih kepada Perpustakaan Fakultas Hukum Universitas $\mathrm{X}$ yang menyediakan buku sebagai referensi dalam menyusul jurnal kelompok kami ini baik dari aspek penulisan ilmiah, konten, materi, maupun metodologi penelitian.

\section{REFERENSI}

Asshiddiqie, J. (2005). Sengketa kewenangan antar lembaga negara. Jakarta: Konstitusi Press Black, H.C. (1991). Black law dictionary. St. Paul: West Group.

Fadjar, M. (2009). Mahkamah konstitusi sebagai pelaku kekuasaan kehakiman, Bahan Kuliah Program Doktor. Universitas Brawijaya.

Hendra, W.F. (1995). Advokat indonesia citra, idealisme dan keprihatinan. Jakarta: Pustaka Sinar Harapan.

http://kbbi.web.id/pasti, pada tanggal 1 September 2018 pukul 09.00 .

https://www.republika.co.id/berita/kolom/wacana/18/01/19/p2s7rv440-hakimunitas-advokat, pada tanggal 5 September 2018 pukul 13.50

Koehn, D. (2000). Landasan etika profesi. Yogyakarta: Kanisius.

Krisharyanto, E. (2007). Profesi advokat dalam penegakan hukum, Disertasi. Universitas Airlangga.

Sahetapy, J.E. (1996). Hukum pidana. Liberty: Yogyakarta: Liberty.

Solehoddin. (2009). Implikasi perubahan UUD NRI 1945 terhadap independensi advokat. Jurnal Konstitusi PPK, 1(1).

Undang-Undang Dasar 1945

Undang-Undang Nomor 18 Tahun 2003 tentang Advokat

Winata, F.H. (1995). Advokat indonesia citra, idealisme dan keprihatinan. Jakarta: Sinar Harapan.

Wisnobroto, A. (1997). Hakim dan peradilan di indonesia dalam beberapa aspek kajian. Yogyakarta: Universitas Atmajaya. 